\title{
Effect of Chemokine Receptors CCR7 on Disseminated Behavior of Human T cell Lymphoma: clinical and experimental study
}

\author{
Jing Yang ${ }^{1 \dagger}$, Shengyi Wang ${ }^{2 \dagger}$, Guofan Zhao ${ }^{1 \dagger}$ and Baocun Sun ${ }^{3^{*+}}$
}

\begin{abstract}
Background: The expression of chemokine receptors CCR7 has been studied in relation to tumor dissemination and poor prognosis in a limited number of cancers. No such studies have been done on CCR7 expression in nonHodgkin's lymphoma (T-NHL). Our aim in this paper is to investigate the association between CCR7 expression and progression and prognosis of T-NHL.

Methods: 1) Analysis of clinical data: The specimens were obtained from 41 patients with T-NHL and 19 patients with lymphoid hyperplasia. Their corresponding clinicopathologic data were also collected. The expression levels of CCR7, MMP-2, and MMP-9 were examined by immunohistochemical staining. 2) Human T-NHL cell lines Hut 78 (cutaneous T-cell lymphoma) and Jurkat (adult T-cell leukemia/lymphoma) were cultured. The invasiveness of the two cell lines were measured with a Transwell invasion assay, and then used to study the effects of chemokine receptors on T-NHL invasion and the underlying molecular mechanism. The transcript and expression of CCR7 were evaluated using RT-PCR and western blotting.

Results: 1) The higher CCR7 and MMP-9 expression ratios were significantly associated with multiple lesions and higher stage III/IV. Moreover, a positive correlation was observed between CCR7 and MMP-9 expression. 2) The Hut 78 cell line was more invasive than the Jurkat cells in the Transwell invasion assay. The transcript and expression levels of CCR7 were significantly higher in Hut78 than that of Jurkat cell line. The T-NHL cell lines were co-cultured with chemokine CCL21 which increased the invasiveness of T-NHL cell. The positive association between CCL21 concentration and invasiveness was found. 3) The stronger transcript and expression of $\mathrm{Pl}_{3} \mathrm{~K}, \mathrm{Akt}$ and $\mathrm{p}$ - Akt were also observed in Hut78 than in Jurkat cell line.
\end{abstract}

Conclusions: High CCR7 expression in T-NHL cells is significantly associated with lymphatic and distant dissemination as well as with tumor cell migration and invasion in vitro. Its underlying mechanism probably involves the $\mathrm{Pl}_{3} \mathrm{~K} / \mathrm{Akt}$ signal pathway.

\section{Background}

Currently, tumor growth and metastatic dissemination result from a complex, dysregulated molecular machinery, leading to resistance of tumor cells to apoptosis, tumor cell migration, tumor cell invasion, and tumor cell immune escape mechanisms. Recent data suggest that chemokine receptors may direct lymphatic and

\footnotetext{
* Correspondence: sunbaocun@yahoo.com.cn

+ Contributed equally

${ }^{3}$ Department of Pathology and Cancer Hospital of Tianjin Medical University, Tianjin, China

Full list of author information is available at the end of the article
}

hematogenous spread, and may additionally influence the sites of metastatic growth of different tumors[1].

Chemokine receptors are GTP-proteins linked to 7 transmembrane domains and they are expressed on the cell membranes of immune and endothelial cells. CCR7, the receptor for chemokine CCL21, was first discovered on B cells infected by Epstein-Barr virus [2]. It is often expressed on naive $\mathrm{T}$ cells, memory $\mathrm{T}$ cells, B cells, and mature dendritic cells [3,4]. CCR7 is important for lymphatic cell migration and chemotaxis to lymph nodes. CCR7 has two ligands, CCL19 and CCL21. CCL21 and CCR7 are very important for $\mathrm{T}$ cell migration, activation, and existence, especially for lymphocytic chemotaxis.

\section{Biomed Central}


The prominent biological behavior of T-NHL is invasion. Patients often visit doctors when they develop multiple disseminated tumor sites. Normal T cells express CCR7, and when cancer occurs, we have been unable to determine if chemokine receptor expression increase and whether it promoted tumor growth and dissemination. The role of chemokine receptors in tumor spreading has been the focus of recent studies. High CCR7 expression has been associated with lymph node metastases and poor prognosis in oral squamous cell carcinoma and melanoma [5,6]. Supporting data from in vitro and murine tumor models underline the key roles of two receptors, CCR7 and CXCR4 in tumor cell malignancy. Stimulation of CCR7 by its ligand CCL21 induces migration and invasion of CCR7-expressing cancer cells [7]. Furthermore, inhibition of the chemokine receptors, such as CXCR4 and SDF-1, could suppress chemokine-induced migration, invasion, and angiogenesis [8,9]. However, no studies have been done on CCR7 expression in human T-NHL and its effects on disease progression and prognosis. Therefore, we evaluated CCR7 expression in T-NHL cell lines and specimens, and analyzed its correlation with clinicopathologic parameters of patients. Our results reveal that high CCR7 expression significantly influences lymphatic and hematogenous tumor dissemination, and also correlates with clinical staging. Moreover, we investigated the underlying mechanisms. We found that high CCR7 expression is associated with lymphatic and distant dissemination in patients with T-NHL, probably via the PI3K/Akt signal pathway.

\section{Methods \\ Clinical Data \\ Materials}

We collected 41 specimens of T-cell non-Hodgkin's lymphoma and 19 lymph nodes of reactive hyperplasia from 2003 to 2008 in the General Hospital of Tianjin Medical University. All specimens were formalin-fixed and embedded in paraffin. Not all patients underwent treatment on their visits. Of the $41 \mathrm{~T}$-NHL patients, 23 were males and 18 were females. The mean age was $48.34 \pm 16.19$ years. According to the WHO classification, the histological types of the specimens in our study included peripheral $\mathrm{T}$ cell lymphoma, not otherwise characterized (32 cases), extranodal NK/T cell lymphoma, nasal type (5 cases), anaplastic large cell lymphoma (2 cases), and angioimmunoblastic $\mathrm{T}$ cell lymphoma ( 2 cases).

\section{Method}

Immunohistochemical Staining The avidin-biotin complex method was used to detect the CCR7 (anti-CCR7, 1:300 dilution; Epitomics Inc.), MMP-2 (anti-MMP-2, 1:250 dilution; Zhong Shan Inc., Beijing), and MMP-9
(anti-MMP-9, 1:250 dilution; Zhong Shan Inc., Beijing). The formalin-fixed, paraffin-embedded tissues were deparaffinized and subsequently heated in a microwave oven with EDTA buffer. After preincubation with hydrogen peroxide, an avidin/biotin blocking kit, and rabbit serum, the primary antibodies were applied overnight in the wet box at $4^{\circ} \mathrm{C}$, and then incubated with the secondary antibodies (rabbit anti-goat biotinylated; 1:200 dilution, ZhongShan Inc., Beijing) for about $50 \mathrm{~min}$. At last avidin-biotin complex was added, and enzyme activity was visualized with diaminobenzidine. Counterstaining was done with hematoxylin. For the negative controls, only the secondary antibodies were used. A negative control was done for every lymphoma and reactive lymph node sample $(n=60)$. For the positive controls, formalin-fixed, paraffin-embedded tissue samples of the human spleen were applied.

Evaluation of Immunohistochemical Staining Immunohistochemical staining was independently evaluated by four authors, blinded to patient outcome and all clinicopathologic findings. The immunohistochemical staining was analyzed according to staining index, which was calculated by multiplying the score for staining intensity $(0$, absent, no color in tumor cells; 1 , weak, pale yellow in tumor cells; 2, intermediate, yellow in tumor cells; 3 , strong staining, brown yellow in tumor cells) with the score for percentage of stained tumor cells $(0$, positive cells account for $0 \%-10 \% ; 1,11 \%-25 \%$; $2,26 \%-50 \%$; 3 , $>50 \%)$. The staining index value ranges from 0 to 9 . The specimens grouped by staining index value as $-(<2),+$ $(2-4),++(5-7),+++(8-9)$. The slide of ++ or higher than ++ was classified as high expression. Otherwise, the slide was classified as low expression. The slides were usually evaluated by four observers. The final classification of a slide was determined by the value agreed to by a majority of observers.

\section{In vitro Experimentation \\ Materials}

Cell Culture The human cutaneous $\mathrm{T}$ cell lymphoma cell line Hut78 and the adult T lymphocytic leukemia/ lymphoma Jurkat cell line were inoculated into cellular culture boards with improved 1640 medium supplemented with $10 \%$ fetal bovine serum (Hyclone, Inc., USA), 100 units $/ \mathrm{mL}$ penicillin, $100 \mu \mathrm{g} / \mathrm{mL}$ streptomycin (Cambrex, East Rutherford, NJ), and $1 \mathrm{mmol} / \mathrm{L} \mathrm{L}$-glutamine. CCL21 were mixed into media to final concentrations of 50 ( $\mathrm{S}_{50}$ group), $100\left(\mathrm{~S}_{100}\right.$ group), and $200 \mathrm{nmol} / \mathrm{L}\left(\mathrm{S}_{200}\right.$ group). Two cell lines were aggregated and grown in the same suspension.

\section{Method}

RNA Isolation and Semiquantitative Reverse Transcriptase Polymerase Chain Reaction (RT-PCR) RNA isolation was done using the RNeasy Kit according to 
the manufacturer's recommendations (Biomiga Inc., American). Gene transcriptions of actin, CCR7, PI3K, and Akt were analyzed via a two-step RT-PCR. Reverse transcription was done with $2 \mu \mathrm{g}$ of RNA $(20 \mu \mathrm{L}$ total volume; Omniscript RT Kit, Qiagen) according to the manufacturer's recommendations. Up to $1 \mu \mathrm{L}$ of cDNA was used as a template for the specific PCR reactions. The primers used were as follows: $\beta$-actin, forward 5'CCTGGGCATGGAGTCCTGTG-3' and reverse 5'AGGGGCCGGACTCGTCATAC-3' (305 bp fragment); CCR7, forward 5'-TCCTTCTCATCAGCAAGCTGTC-3' and reverse 5'-GAGGCAGCCCAGGTCCTTGAA-3' (529 bp fragment); PI3K, forward 5'-CATCACTTCC TCCTGCTCTAT-3' and reverse 5'-CAGTTGTTGGCAATCTTCTTC-3' (377 bp fragment); Akt, forward 5'GGACAACCGCCATCCAGACT-3' and reverse 5'GCCAGGGACACCTCCATCTC-3' (121 bp fragment). For amplification, a DNA Engine PTC200 (MJ Research, Watertown, MA) thermocycler was used. The cycling conditions for the respective PCRs were as follows: initial denaturation $\left(10 \mathrm{~min}\right.$ at $\left.95{ }^{\circ} \mathrm{C}\right)$ followed by 35 cycles of denaturation $\left(30 \mathrm{~s}\right.$ at $\left.94{ }^{\circ} \mathrm{C}\right)$, annealing $(30 \mathrm{~s}$ at the following temperatures: $\beta$-actin, $59{ }^{\circ} \mathrm{C}$; CCR7, $53{ }^{\circ} \mathrm{C}$; PI3K, $53{ }^{\circ} \mathrm{C}$; Akt, $\left.56{ }^{\circ} \mathrm{C}\right)$, and elongation $\left(1 \mathrm{~min}\right.$ at $72^{\circ}$ C). After the last cycle, a final extension (10 min at $72^{\circ}$ C) was added and, thereafter, the samples were kept at $4{ }^{\circ} \mathrm{C}$. Then, $5 \mu \mathrm{L}$ of the products were run on a $1 \%$ agarose gel under a constant voltage of $100 \mathrm{~V}$ for 20 min, stained with ethidium bromide, and then analyzed it under UV light.

Western Blot Analysis Hut 78 and Jurkat cells were washed in PBS and lysed in RIPA lysate solution (Solarbio Inc.). Then, $100 \mu \mathrm{g}$ of protein were separated by $10 \%$ SDS-PAGE. After separation, the protein were transferred from the gel onto a polyvinylidene difluoride membrane. The respective proteins were detected by anti-CCR7 (1:3000, Epitomics Inc., 1:1000 rabbit antigoat IgG second antibodies, Zhongshan Inc., Beijing), anti-Akt (1:1000, Beyotime Inc., Shanghai, 1:1000 rabbit anti-goat IgG second antibodies, Zhongshan Inc., Beijing), anti-p-Akt (1:2000, Epitomics Inc., 1:1000 rabbit anti-goat IgG second antibody, Zhongshan Inc., Beijing), and anti-GAPDH (1:1000, Santa Cruz, America; 1:1000 goat anti-rabbit IgG second antibodies, ZhongShan Inc., Beijing), and were visualized with an ECL Western blotting analysis system.

Cellular Invasion Assays Invasiveness assays of Hut 78 and Jurkat cells were performed in a Transwell chamber. ( $8 \mu \mathrm{m}$ pore size; Corning Inc.). Each group of cells was centrifuged and washed in PBS, resuspended with supernatant, and adjusted to a cellular density of $5 \times 10^{5}$. Then, $100 \mu \mathrm{L}$ of the cell suspension from each group was placed into the upper Transwell chambers and 600 $\mu \mathrm{L}$ of culture fluid with the corresponding CCL21 concentration was placed into the lower chamber. The chambers were then incubated for 24 hours at $37{ }^{\circ} \mathrm{C}$ in a humid atmosphere of $5 \% \mathrm{CO}_{2}$. After incubation, the number of cells that migrated to the lower chamber was determined with eosin staining. The cells entered the substrate in the lower chamber and then were mixed uniformly. At last, we counted the cells under the microscope (10 randomly selected high power fields) individually.

\section{Statistical Analysis}

Data were analyzed with SPSS 11.5 software. Statistics processing about clinical data were evaluated with $\chi^{2}$ test, Spearman's rank correlation test. Statistics processing about in vitro experimentation were t test and ANOVA. $\mathrm{P}<0.05$ was considered significant and $\mathrm{P}<$ 0.001 highly significant in all statistical analyses.

\section{Results}

Immunohistochemical Staining of CCR7, MMP-9, and MMP-2 (Table 1)

The result for CCR7, MMP-9, and MMP-2 revealed a predominantly cytoplasmic staining. A focal weak membrane staining (Figure 1) was observed. The high expression ratio of CCR7, MMP-9, and MMP-2 were 82.9\%, $87.8 \%$, and $70.7 \%$ in T-NHL specimens, respectively. All markers' high expression ratios were higher than that in hyperplastic lymph node group $(\mathrm{P}<0.01)$.

\section{Expression of all parameters in T-NHL group and correlation with clinical parameters}

(1) There was no significant correlation of high CCR7 expression ratio with age $(87.5 \%>60$ years vs $81.8 \%<=60$ years), sex (87\% males vs. $77.8 \%$ females) and tumor size $(88.0 \%>3 \mathrm{~cm}$ vs. $75.0 \%<3 \mathrm{~cm}$ ) (Table 2$)$. The positive correlation between high CCR7 expression and multiple location dissemination was found. The CCR7 expression ratio of the multiple locations group was higher than that in the single location group $(92.6 \%$ vs. $64.3 \%, P<0.05)$. Concerning WHO classification, the high expression ratio of CCR7 also was highly significantly associated with higher tumor UIUC stages. UICC stage III and IV group had 100\% high CCR7 expression compared with $75 \%$ in UICC stage I and II group $(P<0.05)$.

Table 1 The chemokine receptor expression ratios of TNHL group and comparison group [number of cases (\%)]

\begin{tabular}{lcccc}
\hline Group & $\mathbf{n}$ & CCR7 & MMP-9 & MMP-2 \\
\hline T-NHL group & 41 & $34(82.9)$ & $36(87.8)$ & $29(70.7)$ \\
Control group & 19 & $3(15.8)$ & $3(15.8)$ & $2(10.5)$ \\
$\chi^{2}$ & & $32.219^{*}$ & $29.598^{*}$ & $18.845^{*}$ \\
\hline
\end{tabular}

${ }^{*} P<0.01$ 


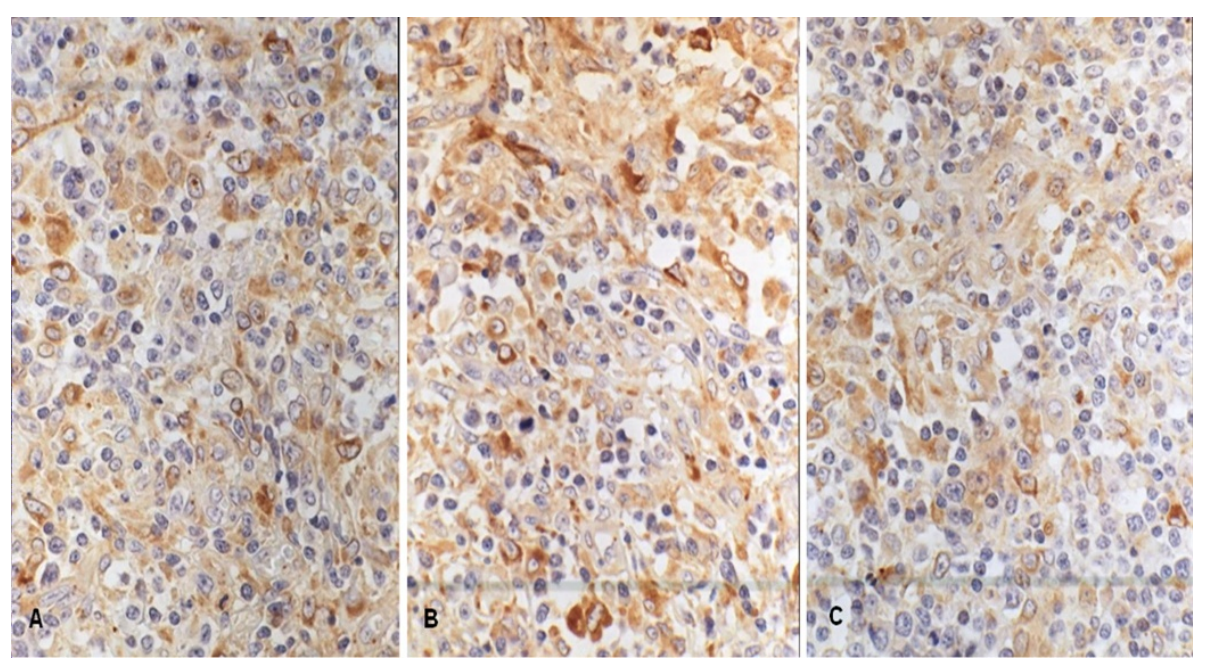

Figure 1 The expression of CCR7, MMP-9 and MMP-2 in T-NHL with immunohistochemical staining. These markers all express in the cytoplasm. Some yellow or brown yellow granules in the cytoplasm are postive. The immunohistochemical staining was performed with S-P method and these photoes were taken under the high power $(\times 400)$. A was CCR7 stainting. The staining intensity is strong. B was MMP-9 stainting. The staining intensity is strong. $C$ was MMP-2 staining. The staining intensity is intermediate.

(2) The MMP-9 expression ratio in the multiple locations group (96.3\%) was higher than that in the single location group (71.4\%), in the clinical stage III-IV group $(100 \%)$ than that in the clinical stage I-II group (79.2\%), and in the $>3 \mathrm{~cm}$ tumor size group that in the $\leq 3 \mathrm{~cm}$ group (96\% vs. $75 \%, P<0.05)$. MMP-9 expression ratio showed no signification difference in gender and age.

Table 2 The correlation between clinical parameters and higher expression of the three pathological parameters [number of cases (\%)]

\begin{tabular}{|c|c|c|c|c|}
\hline Clinical-Pathology & $\mathbf{n}$ & CCR7 & MMP-9 & MMP-2 \\
\hline \multicolumn{5}{|l|}{ Sex } \\
\hline Male & 23 & $20(87.0)$ & $20(87.0)$ & $18(78.3)$ \\
\hline Female & 18 & $14(77.8)$ & $16(88.9)$ & $11(61.1)$ \\
\hline \multicolumn{5}{|l|}{ Age } \\
\hline$\leq 60$ years & 33 & $27(81.8)$ & $29(87.9)$ & $25(75.8)$ \\
\hline$>60$ years & 8 & $7(87.5)$ & $7(87.9)$ & $4(50)$ \\
\hline \multicolumn{5}{|l|}{ Tumor size } \\
\hline$\leq 3 \mathrm{~cm}$ & 16 & $12(75.0)$ & $12(75.0) *$ & $13(81.3)$ \\
\hline$>3 \mathrm{~cm}$ & 25 & $22(88.0)$ & $24(96.0) *$ & $16(64)$ \\
\hline \multicolumn{5}{|l|}{ Clinical Stage } \\
\hline Stage I-II & 24 & $18(75.0) *$ & $19(79.2) *$ & $20(83.3) *$ \\
\hline Stage III-IV & 17 & $17(100.0) *$ & $17(100.0) *$ & $9(52.9) *$ \\
\hline \multicolumn{5}{|l|}{ B symptom } \\
\hline No & 16 & $13(81.3)$ & $13(81.3)$ & $11(68.8)$ \\
\hline Yes & 25 & $21(84.0)$ & $23(92.0)$ & $18(72)$ \\
\hline \multicolumn{5}{|l|}{ Location } \\
\hline Single location & 14 & $9(64.3) *$ & $10(71.4) *$ & $12(85.7) *$ \\
\hline Multiple location & 27 & $25(92.6) *$ & $26(96.3) *$ & $17(63) *$ \\
\hline
\end{tabular}

The highly positive correlations of MMP-9 expression ratio with multiple location dissemination, higher UICC stages and larger tumor size were observed. (Table 2);

(3) Contrary to CCR7 and MMP-9, MMP-2 showed higher expression in single location group compared with multiple locations group $(52.9 \%$ vs. $83.3 \%, P<$ $0.05)$. MMP-2 expression was also significantly associated with lower UIUC stages ( $83.3 \%$ vs $52.9 \%$ ).

(4) Other clinical parameters without statistical significance were not included in the table.

\section{Correlation among all indices in T-NHL}

The high expression of CCR7, MMP-9, and MMP-2 in T-NHL was analyzed with Spearman's correlation analysis. The relationship between CCR7 and MMP-9 ( $\mathrm{rs}=$ $0.395, P<0.05)$ expressed direct correlation. The relationship among other markers showed no significant correlation $(P>0.05)$.

Table 3 Cellular count in the lower chamber in Transwell invasion experiment $(\bar{x} \pm s, \mathbf{n}=9)$

\begin{tabular}{lllll}
\hline & $\begin{array}{l}\text { Control } \\
\text { group }\end{array}$ & $\mathrm{S}_{50}$ group & $\mathrm{S}_{100}$ group & $\mathrm{S}_{\mathbf{2 0 0}}$ group \\
\hline Jurkat & $10.63 \pm 5.52$ & $20.70 \pm 8.40^{\star \star}$ & $33.43 \pm$ & $49.13 \pm$ \\
& & & $10.61^{\star \star}$ & $21.01^{\star 3}$ \\
Hut & $15.00 \pm 6.48^{\star}$ & $35.37 \pm$ & $42.26 \pm$ & $72.60 \pm$ \\
78 & & $18.21^{\star^{\star}}$ & $20.17^{\star}$ & $34.12^{\star^{\Delta}}$ \\
\hline
\end{tabular}

${ }^{*}$ Compared with corresponding group of Jurkat cells, $P<0.01$;

${ }^{2}$ Compared with the other groups of Jurkat cells (including the control group), $P<0.01$

"Compared with the control group and of $S_{200}$ group of Hut 78 cells, $P<0.01$; "Compared with the other groups of Hut 78 cells (including the control group), $P<0.01$. 
Transwell invasion experiment result (Table 3)

In the lower chamber, there were more Hut 78 cells than Jurkat cells in all groups except $S_{100}$ group $(P<0.01)$.

The number of Hut 78 and Jurkat cells that penetrated the membrane in the $S_{50}, S_{100}$, and $S_{200}$ groups were all higher than that in the control group $(P<0.01)$.

For the Hut 78 cell line, the cells in the $S_{200}$ group were higher than that in the $S_{50}$ group, whereas for the Jurkat cell line, the cells in the $S_{100}$ group were higher than that in $S_{50}$ group, and the cells in $S_{200}$ were higher than that in $\mathrm{S} 100$ group $(\mathrm{P}<0.01)$.

The expression and transcript of CCR7 in two cell lines under conventional culture and CCL21 co-culture

(1) CCR7mRNA transcript (Table 4, Figure 2)

According to the relative grey scale, the numbers of CCR7 transcripts of the two cell lines in all concentration groups were higher than that in the control group $(P<0.01)$.

The CCR7 transcripts of the Hut 78 cells in control, $S_{50}$, and $S_{100}$ groups were higher than that in the corresponding groups of Jurkat cells $(P<0.01)$.

The CCR7 transcripts of the two cell lines in the higher concentration group were higher than that in the lower concentration group, except for $S_{100}$ and $S_{200}$ groups in the Hut 78 cell line $(P<0.01)$.

\section{(2) Expression of CCR7 protein (Table 5, Figure 2)}

In both cell lines, the relative expression of the CCR7 protein in the $S_{100}$ and $S_{200}$ groups were higher than that in the control group, whereas the CCR7 expression in the $S_{100}$ group was higher than that in the $S_{50}$ group $(P<0.01)$.

The CCR7 expression of the Hut 78 cell line in the control, $S_{50}, S_{100}$, and $S_{200}$ groups were higher than those of the Jurkat cell line $(P<0.01)$.

The expression and activation of $\mathrm{Pl}_{3} \mathrm{~K} / \mathrm{Akt}$ pathway in the two cell lines under conventional culture and CCL21 coculture

(1) $\mathrm{PI}_{3} \mathrm{~K}$ mRNA transcript (Table 6, Figure 3)

The relative $\mathrm{PI}_{3} \mathrm{~K}$ mRNA expression levels in all concentration groups were higher than that in the control

Table 4 The relative grey scale of CCR7mRNA transcript $(\bar{x} \pm \mathbf{s}, \mathbf{n}=9)$

\begin{tabular}{|c|c|c|c|c|}
\hline & $\begin{array}{l}\text { Control } \\
\text { group }\end{array}$ & $S_{50}$ group & $S_{100}$ group & $\mathrm{S}_{200}$ group \\
\hline Jurkat & $\begin{array}{c}0.1512 \pm \\
0.0278\end{array}$ & $\begin{array}{l}0.4604 \pm \\
0.0331^{ \pm t}\end{array}$ & $\begin{array}{l}0.7453 \pm \\
0.0636^{ \pm t}\end{array}$ & $\begin{array}{l}0.9071 \pm \\
0.4985^{\frac{t^{2}}{2}}\end{array}$ \\
\hline $\begin{array}{l}\text { Hut } \\
78\end{array}$ & $\begin{array}{c}0.5282 \pm \\
0.0537^{\star}\end{array}$ & $\begin{array}{l}0.6943 \pm \\
0.0365^{\star^{\star}}\end{array}$ & $\begin{array}{l}0.8477 \pm \\
0.0513^{\star \star}\end{array}$ & $\begin{array}{c}0.8710 \pm \\
0.0485\end{array}$ \\
\hline
\end{tabular}

${ }^{\star}$ Compared with the corresponding group of Jurkat cells, $P<0.01$;

${ }^{2}$ Compared with the other groups of Jurkat cells (including the control group), $P<0.01$;

"Compared with the control group and S50 group of Hut 78 cells, $P<0.01$;

${ }^{\circ}$ Compared with the other groups of Hut 78 cells (including the control group), $P<0.01$.

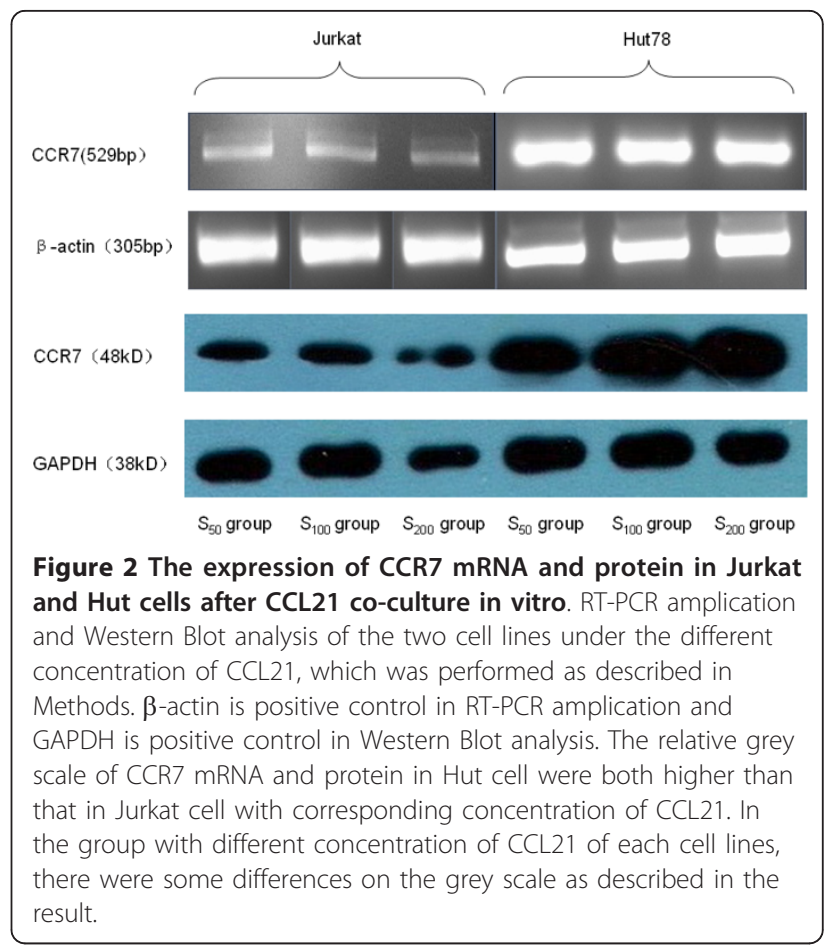

group $(P<0.01)$. The relative $\mathrm{PI}_{3} \mathrm{~K}$ mRNA expression levels of the Jurkat cells in the $S_{100}$ and $S_{200}$ groups were both higher than that in the $S_{50}$ group. The expression in the $S_{200}$ group was lower than that in the $\mathrm{S}_{100}$ group $(P<0.05)$. For the Hut 78 cells, there were no significant differences in relative expression levels in all three concentration groups. The relative expression levels in the control and $S_{200}$ groups were both higher than that in the Jurkat cells. The relative expression levels had no significant differences between Hut 78 and Jurkat cells in $S_{50}$ and $S_{100}$ groups.

\section{(2) Akt mRNA transcript (Table 7, Figure 4)}

The relative Akt mRNA expression levels in all concentration groups were higher than that in the control group $(P<0.01)$. The relative Akt mRNA expression levels of the Hut 78 cells in the control, $S_{50}, S_{100}$, and $\mathrm{S}_{200}$ groups were all higher than those of the Jurkat cells $(P<0.05)$. The relative expression levels of the two cell

Table 5 The relative grey scale of CCR7 protein $(\bar{x} \pm s$, $\mathrm{n}=9$ )

\begin{tabular}{|c|c|c|c|c|}
\hline & $\begin{array}{l}\text { Control } \\
\text { group }\end{array}$ & $S_{50}$ group & $\mathrm{S}_{100}$ group & $\mathrm{S}_{200}$ group \\
\hline Jurkat & $\begin{array}{c}0.5053 \pm \\
0.0336\end{array}$ & $\begin{array}{c}0.4870 \pm \\
0.0278\end{array}$ & $\begin{array}{l}0.6916 \pm \\
0.0238^{ \pm 2}\end{array}$ & $\begin{array}{l}0.7095 \pm \\
0.0332^{\frac{2}{2}}\end{array}$ \\
\hline $\begin{array}{l}\text { Hut } \\
78\end{array}$ & $\begin{array}{c}1.1037 \pm \\
0.1135^{\star}\end{array}$ & $\begin{array}{c}1.0700 \pm \\
0.1121^{\star}\end{array}$ & $\begin{array}{l}1.4792 \pm \\
0.250 \star^{\star}\end{array}$ & $\begin{array}{l}1.4804 \pm \\
0.2524^{\star}\end{array}$ \\
\hline
\end{tabular}

${ }^{\star}$ Compared with the corresponding group of Jurkat cells, $P<0.01$;

${ }^{2}$ Compared with the control group and the $S_{50}$ group of Jurkat cells, $P<0.01$; 'Compared with the control group and the $S_{50}$ group of Hut 78 cells, $P<$ 0.01 
Table 6 The relative grey scale of $\mathrm{Pl}_{3} \operatorname{KmRNA}(\bar{x} \pm s, \mathbf{n}=9$ )

\begin{tabular}{|c|c|c|c|c|}
\hline & $\begin{array}{l}\text { Control } \\
\text { group }\end{array}$ & $\mathrm{S}_{50}$ group & $\mathrm{S}_{100}$ group & $\mathrm{S}_{200}$ group \\
\hline Jurkat & $\begin{array}{l}0.2170 \pm \\
0.0289\end{array}$ & $\begin{array}{l}0.7897 \pm \\
0.0549^{ \pm 2}\end{array}$ & $\begin{array}{l}0.8310 \pm \\
0.0377^{\text {妳 }}\end{array}$ & $\begin{array}{c}0.8248 \pm \\
0.0381^{\star}\end{array}$ \\
\hline $\begin{array}{l}\text { Hut } \\
78\end{array}$ & $\begin{array}{l}0.6061 \pm \\
0.0545^{\#}\end{array}$ & $\begin{array}{c}0.7996 \pm \\
0.0200\end{array}$ & $\begin{array}{c}0.8365 \pm \\
0.0346\end{array}$ & $\begin{array}{l}0.8759 \pm \\
0.0467^{\star^{\star} *}\end{array}$ \\
\hline
\end{tabular}

${ }^{*}$ Compared with the corresponding group of Jurkat cells, $P<0.05$;

\# Compared with the corresponding group of Jurkat cells, $P<0.01$;

Compared with the control group of the Jurkat cells, $P<0.01$;

"Compared with the other groups of Jurkat cells, including the control group, $P<0.05$;

"Compared with the control group of Hut 78 cells, $P<0.01$;

* Compared with the $S_{50}$ group of Hut 78 cells, $P<0.01$.

lines in the higher concentration group were significantly higher than that in lower concentration group (Table 7).

\section{(3) p-Akt protein expression (Table 8, Figure 4)}

For the Hut 78 cells, the relative p-Akt protein expression levels in all concentration groups were all significantly higher than that in control group. The expression in the $S_{100}$ group was significantly higher than those in the $S_{50}$ and $S_{200}$ groups.

For the Jurkat cells, the relative p-Akt protein expression levels of in the $S_{100}$ and $S_{200}$ groups were significantly higher than that in the control group and the expression in the higher concentration group was significantly higher than that in the lower concentration group.

The relative expression levels of Hut 78 cells in the control, $S_{50}, S_{100}$, and $S_{200}$ groups were higher than those of Jurkat cells.

\section{Discussion}

This is the first study analyzing the expression profiles of CCR7 chemokine receptors in a larger series of human $\mathrm{T}$ cell lymphoma tissues and cell lines. We further determined whether CCR7 expression influenced tumor cell migration in vitro and the metastatic

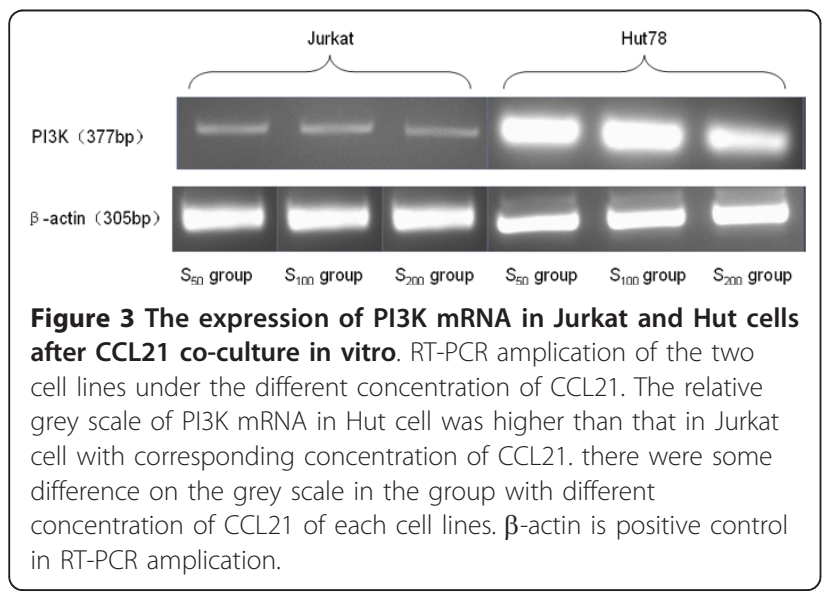

Table 7 The relative grey scale of the Akt mRNA $(\bar{x} \pm s$, $\mathbf{n}=9$ )

\begin{tabular}{|c|c|c|c|c|}
\hline & $\begin{array}{l}\text { Control } \\
\text { group }\end{array}$ & $S_{50}$ group & $S_{100}$ group & $S_{200}$ group \\
\hline Jurkat & $\begin{array}{c}0.1808 \pm \\
0.0264\end{array}$ & $\begin{array}{l}0.3224 \pm \\
0.0172^{2 \sqrt{2 k}}\end{array}$ & $\begin{array}{l}0.5194 \pm \\
0.0340^{\frac{25}{23}}\end{array}$ & $\begin{array}{l}0.6305 \pm \\
0.0212^{\frac{2 \sqrt{2}}{3}}\end{array}$ \\
\hline $\begin{array}{l}\text { Hut } \\
78\end{array}$ & $\begin{array}{l}0.2279 \pm \\
0.0183^{\star}\end{array}$ & $\begin{array}{l}0.6418 \pm \\
0.0344^{\star \Delta}\end{array}$ & $\begin{array}{l}0.7107 \pm \\
0.0149^{\star \Delta}\end{array}$ & $\begin{array}{l}0.7325 \pm \\
0.0234^{\star \Delta}\end{array}$ \\
\hline
\end{tabular}

${ }^{\star}$ Compared with the corresponding group of Jurkat cells, $P<0.01$;

${ }^{25}$ Compared with the other groups of Jurkat cells, including the control group, $P<0.01$;

${ }^{\circ}$ Compared with the other groups of Hut 78 cells, including the control group, $P<0.05$.

behavior of T-NHL and its prognosis in patients, as recently reported for many other malignant tumors. In 2001, Müller [10] first reported breast carcinoma with higher expression of a CCR7 chemokine receptor in primary and metastatic foci. He also found high expression of CCL21 in metastatic sites, such as lymph node, lung, liver, and bone marrow. In an in vitro experiment, he found that SDF-1 increased F actin expression in the tumor cells, which can form pseudopodia. In addition, CCL21 also induced breast carcinoma cell migration and basement membrane invasion. CCR7 expression has previously been associated with intrapleural dissemination in non-small cell lung cancer [11], gastric carcinoma [12], and so on, implying the relevant function of CCR7 expressing during carcinogenesis in these cancers. The theory of a CCR7-co-mediated mechanism of lymphatic dissemination was also supported by an animal study, revealing that the CCR7 expression of melanoma cells increases metastases formation in the regional lymph nodes of mice [13]. Moreover, using monoclonal

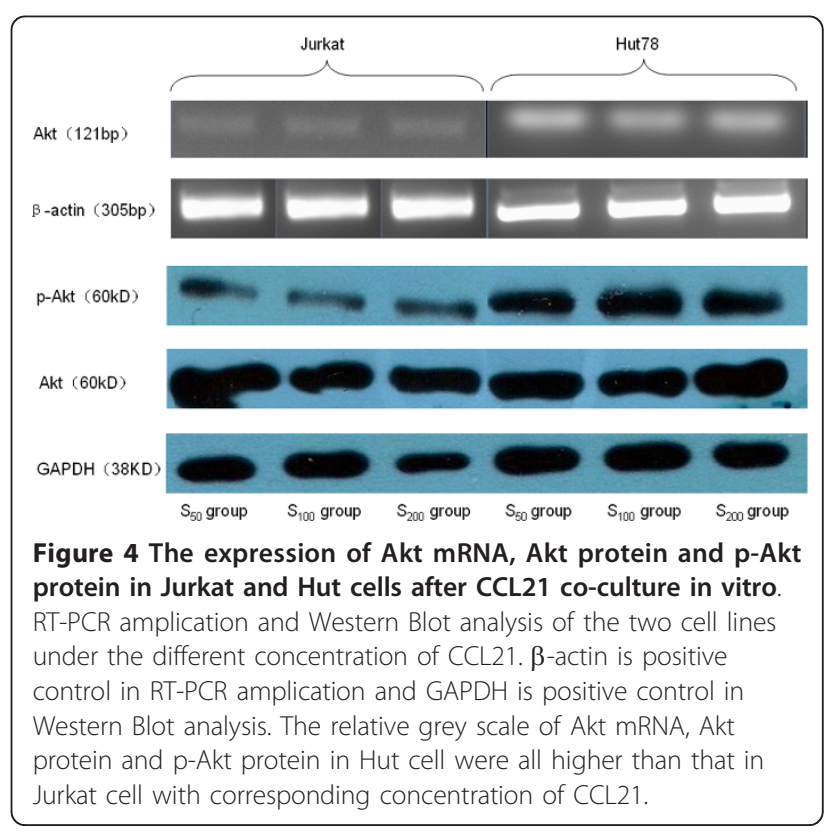


Table 8 The relative grey scale of $p$-Akt protein after coculture $(\bar{x} \pm \mathbf{s}, \mathbf{n}=9$ )

\begin{tabular}{|c|c|c|c|c|}
\hline & $\begin{array}{l}\text { Control } \\
\text { group }\end{array}$ & $S_{50}$ group & $S_{100}$ group & $S_{200}$ group \\
\hline Jurkat & $\begin{array}{c}0.5523 \pm \\
0.0112\end{array}$ & $\begin{array}{l}0.5680 \pm \\
0.0566^{\wedge}\end{array}$ & $\begin{array}{l}0.7784 \pm \\
0.0694^{2 \sqrt[3]{3}}\end{array}$ & $\begin{array}{l}0.9184 \pm \\
0.0668\end{array}$ \\
\hline $\begin{array}{l}\text { Hut } \\
78\end{array}$ & $\begin{array}{c}0.9171 \pm \\
0.0483^{\star}\end{array}$ & $\begin{array}{l}1.1717 \pm \\
0.1679^{\star *}\end{array}$ & $\begin{array}{l}1.3055 \pm \\
0.0799^{\star}\end{array}$ & $\begin{array}{l}1.1507 \pm \\
0.1010^{\star *}\end{array}$ \\
\hline
\end{tabular}

${ }^{\star}$ Compared with the corresponding group of Jurkat cells, $P<0.01$;

Compared with the other groups of Jurkat cells, including the control group, $P<0.01$

'Compared with the $S_{100}$ and the $S_{200}$ groups of Jurkat cells, $P<0.01$;

"Compared with the other groups of Hut 78 cells, including the control group, $P<0.01$;

* Compared with the control and the $S_{100}$ groups of Hut 78 cells, $P<0.01$.

antibodies against CCL21 could prevent lymph node metastasis. CCR7-mediated lymphatic dissemination had been compared with the chemotaxis of activated dendritic cells to CCL21-expressing lymph nodes via lymphatic vessels $[7,12,14-16]$.

Diverse functional studies investigating the influence of CCR7 expression and the activation by its ligand CCL21 were recently conducted, revealing that CCR7 is crucial for adhesion, migration, and invasion of CCR7-expressing malignant tumors [11-13]. To confirm the function of CCR7 in T-NHL, we performed migration and invasion assays using Hut 78 and Jurkat cells. In the vitro experiment, we found that the invasiveness of Hut 78 cell through a Transwell chamber was higher than that of Jurkat cells. Moreover, the CCR7 mRNA transcript and protein expression of Hut 78 cells were also higher than that of Jurkat cells. The migration of these two CCR7 expressing cell lines was significantly stimulated by CCL21, implying an important role and intact function of CCR7 during tumor progression. The invasion capability of these two cell lines is associated with the CCL21 concentration gradient. However, CCR7 protein expression was no significant difference between $S_{100}$ group and $S_{200}$ group. CCR7 expression in $S_{200}$ group was even lower than that in $S_{100}$ group. Therefore, the ideal CCL21 concentration for CCR7 expression in T cell lymphoma is $50-100 \mathrm{nmol} / \mathrm{L}$. This result is consistent to that in the experiment by Mafei [17]. They proposed that the ideal CCL21 concentration for CCR7 expression in breast carcinoma is $50-500 \mathrm{nmol} / \mathrm{L}$. Under this CCL21 concentration, CCR7 can achieve maximum expression in regulating neoplastic cell chemotaxis and invasion. The concentrations beyond $50-500 \mathrm{nmol} / \mathrm{L}$ could affect CCR7 expression and subsequently influence chemotaxis and invasiveness. These results indicate that the intensity of CCL21-induced cell migration and invasion in vivo correlates with cellular CCR7 expression.

Previous publications have reported that CCR7 activation is critical for metastasis to lymph nodes, lungs, and liver. The mechanism is similar to that of lymphocytic chemotaxis. One study reported that T-cell acute lymphoblastic leukemia is at an increased risk of central nervous system (CNS) relapse. They identified a single chemokine-receptor (CCR7 and CCL19) interaction as a CNS "entry signal" [18]. CCL21 is mainly distributed among peripheral immune organs, especially lymph nodes and spleen. Gunn's study showed that CCL21 could be found in the high endothelial vein of lymph nodes and Peyer's patches, $\mathrm{T}$ lymphatic zones, lymphoid follicles, and endothelial cells of lymphatic vessel in many organs. CCL21 can drive lymphocytes in human T cell line and peripheral blood, but not chemotaxis for neutrophils and monocytes, which suggest that CCL21 is specific for the trafficking of $\mathrm{T}$ lymphocytes [16]. CCL21 has dual effects on malignant tumor formation. CCL21 can attract immune cells and inhibit vascularization, which block tumor growth. Meanwhile, the increase of CCR7 chemokine receptor expression promotes tumor growth and metastasis. When the latter effect is prominent, the tumor disseminates. Under normal conditions, CCR7 is expressed on T cells. When malignancy occurs, the neoplastic $\mathrm{T}$ cell may enhance the expression of CCR7. The differential expression of CCL21 by endothelial cells might explain at least one part of this process. Our results support the chemotaxis theory that CCL21 expression co-mediates the dissemination of primary tumors to different organs [19]. Hasegawa [20] found that adult $\mathrm{T}$ cell leukemia/lymphoma (ATLL) cells with high CCR7 expression have increased directional migration capability toward CCL21, which suggests that CCR7 expression may facilitate ATLL cell movement to the high endothelial vein of lymph nodes with abundant CCL21, and then to metastasis.

The influence of CCL21 on lymphatic dissemination (compared with hematogenous) has not been investigated thus far, but CCL21 is also highly expressed in lymph nodes, and CCR7 inhibition results in suppression of breast cancer lymph node metastases, which implies similar pathways for lymphatic and hematogenous dissemination [10].

$\mathrm{PI}_{3} \mathrm{~K} / \mathrm{Akt}$, an intracellular signal pathway, plays a role in the invasion of many malignant tumors. Whether $\mathrm{PI}_{3} \mathrm{~K} /$ Akt participates in the invasion and metastasis of $\mathrm{T}$ cell lymphomas induced by CCR7 and if a relationship exists between them remains unclear.

The $\mathrm{PI}_{3} \mathrm{~K} /$ Akt signal pathway was first found in the 1990's. The catalysate of PI3K can participate in cellular proliferation, living, differentiation, and migration [21]. Receptor protein tyrosine kinase (RPTK) activation results in $\mathrm{PI}(3,4,5) \mathrm{P}(3)$ and $\mathrm{PI}(3,4) \mathrm{P}(2)$ production by PI3K at the inner side of the plasma membrane. Akt interacts with these phospholipids, causing its translocation to the inner membrane, where it is phosphorylated 
and activated by PDK1 and PDK2. The activated Akt modulates the function of numerous substrates which are involved in the regulation of cell survival, cell cycle progression, and cellular growth.

Several studies have proven that Akt expression is excessively upregulated in many malignant tumors, such as thyroid carcinomas, gliomas, breast carcinomas, pulmonary carcinomas, and so on [22-26]. As a protein kinase, Akt is activated through phosphorylation. The upregulation of Akt protein may promote oncogenesis and tumor growth. The expression level of phosphorylated-Akt is the indicator of the kinase activity.

In our experiment, the expression levels of PI3K mRNA, Akt mRNA, and p-Akt protein in Hut 78 cells were higher than that in Jurkat cells. The Hut 78 cells were more invasive than the Jurkat cells. The invasiveness of T-NHL is associated with the CCR7 expression. CCR7 is a transmembrane receptor of GTP-protein. CCR7 may activate Akt and the PI3K/Akt signal pathway to promote cell proliferation and spread. Noelia [27] reported that CCR7 could activate the intracellular PI3K/Akt signal pathway to promote cell proliferation and suppress apoptosis in DC cells.

We have a hypothesis about how do CCR7 trigger $\mathrm{PI}_{3} \mathrm{~K} /$ Akt signal pathway. The expression of lymph node chemokine in T-NHL could cause the upregulation of chemokine receptors. The interaction between chemokines and their receptors may then activate the Akt protein by peroxodiphosphoric acid, followed by the activation of the $\mathrm{PI}_{3} \mathrm{~K} / \mathrm{Akt}$ signal pathway, which can promote tumor cell proliferation and invasion. This result provides a theoretical foundation for the targeting of CCR7 and the $\mathrm{PI}_{3} \mathrm{~K} /$ Akt signal pathway with antibodies for the treatment of T-NHL. However, further studies on the concrete mechanism of activation of this pathway and its downstream genes are still needed.

In this study, we also detected expression of MMP-9 and MMP-2. MMP is a matrix metalloproteinase that breaks down and destroy Type IV and Type V collagen, as well as gelatin in the extracellular matrix, and then promote tumor metastasis. CCR7 expression in T-NHL was directly correlated with MMP9 expression. High MMP-9 expression has previously been reported in nonHodgkin's lymphoma $[28,29]$, which can influence the biological behavior and clinical progression of tumor. For T-NHL, a report in an animal experiment found that the high expression of MMP-9 is correlated with liver metastasis [30]. The high expression of MMP-9 is also associated with bad prognosis. The relationship between CCR7 and MMP-9 suggests that these two factors may enhance each other and promote tumor dissemination synergistically. However, the function of MMP-2 in T-NHL metastasis is still unclear.

\section{Conclusions}

Higher CCR7 expression in T-NHL cells is significantly associated with lymphatic and distant dissemination in patients, as well as with migratory and invasive phenotypes in vitro. Our study suggested that CCR7 plays an important role in the progression of T-NHL. The possible mechanism is via the $\mathrm{PI}_{3} \mathrm{~K} /$ Akt signal pathway. Further studies are needed to evaluate the inhibition of metastatic growth through blocking CCR7 and $\mathrm{PI}_{3} \mathrm{~K} / \mathrm{Akt}$ signal pathway.

\section{Acknowledgements}

This work was partly supported by a grant from key project of the National Natural Science Foundation of China (No. 30830049), the International cooperation of the Tianjin Natural Science Foundation (CMM-Tianjin, No. 09ZCZDSF04400), Key project of the Tianjin Natural Science Foundation (No. 09JCYBJC12100)

\section{Author details}

${ }^{1}$ Department of Pathology, Tianjin Medical University, Tianjin, China. ${ }^{2}$ Department of Psychology, Tianjin Medical University, Tianjin, China. ${ }^{3}$ Department of Pathology and Cancer Hospital of Tianjin Medical University, Tianjin, China.

\section{Authors' contributions}

$J Y$ participated in the design of the study, and performed the statistical analysis and drafted the manuscript. She also carried out the cellular culture and RT-PCR assay and western blotting analysis. SYW collected clinical data and carried out immunohistochemistry staining and molecular genetic studies. She also helped to perform the statistical analysis. GFZ participated in clinical data collection and carried out the cellular invasion assay. BCS acquired the funding. He also conceived of the study, and participated in its design, and supervised experimental work and helped to draft the manuscript. All authors read and approved the final manuscript.

\section{Competing interests}

The authors declare that they have no competing interests.

Received: 9 March 2011 Accepted: 7 May 2011 Published: 7 May 2011

\section{References}

1. Arya M, Patel HR, Williamson M: Chemokines: key players in cancer. Curr Med Res Opin 2003, 19:557-64.

2. Yoshida R, Nagira M, Kitaura M, Imagawa N, Imai T, Yoshie O: Secondary lymphoid tissue chemokine is a functional ligand for the CC chemokine receptor CCR7. Biol Chem 1998, 273(12):7118-7122.

3. Dieu MC, Vanbervliet $B$, Vicari A, Bridon JM, Oldham E, Aït-Yahia S, Brière $F$, Zlotnik A, Lebecque S, Caux C: Selective recruitment of immature and mature dendritic cells by distinct chemokines expressed in different anatomic sites. Exp Med 1998, 188:373-86.

4. Hirao M, Onai N, Hiroishi K, Watkins SC, Matsushima K, Robbins PD, Lotze MT, Tahara H: CC chemokine receptor-7 on dendritic cells is induced after interaction with apoptotic tumor cells:critical role in migration from the tumor site to draining lymph nodes. Cancer Res 2000, 60:2209-17.

5. Ding Y, Shimada Y, Maeda M, Kawabe A, Kaganoi J, Komoto I, Hashimoto Y, Miyake M, Hashida H, Imamura M: Association of CC chemokine receptor 7 with lymph node metastasis of esophageal squamous cell carcinoma. Clin Cancer Res 2003, 9:3406-12.

6. Takeuchi H, Fujimoto A, Tanaka M, Yamano T, Hsueh E, Hoon DS: CCL21 chemokine regulates chemokine receptor CCR7 bearing malignant melanoma cells. Clin Cancer Res 2004, 10(7):2351-2358.

7. Saeki H, Moore AM, Brown MJ, Hwang ST: Cutting edge: secondary lymphoid-tissue chemokine (SLC) and CC chemokine receptor 7 (CCR7) participate in the emigration pathway of mature dendritic cells from the skin to regional lymph nodes. J Immunol 1999, 162:2472-75. 
8. Mori T, Doi R, Koizumi M, Toyoda E, Ito D, Kami K, Masui T, Fujimoto K, Tamamura H, Hiramatsu K, Fuji N, Imamura M: CXCR4 antagonist inhibits stromal cell-derived factor 1 -induced migration and invasion of human pancreatic cancer. Mol Cancer Ther 2004, 3:29-37.

9. Twitchell DD, London NR, Tomer DP, Tomer S, Murray BK, O'Neill KL: Tannic acid prevents angiogenesis in vivo by inhibiting CXCR4/SDF-1 a binding in breast cancer cells. Proc AACR 2004, 45:abstract 51.

10. Müller A, Homey B, Soto H, Ge N, Catron D, Buchanan ME, McClanahan T, Murphy E, Yuan W, Wagner SN, Barrera JL, Mohar A, Verástegui E, Zlotnik A: Involvement of chemokine receptors in breast cancer metastasis. Nature 2001, 410:50-6.

11. Takanami I: Over expression of CCR7 mRNA in nonsmall cell lung cancer: correlation with lymph node metastasis. Int J Cancer 2003, 105(2):186-189.

12. Mashino K, Sadanaga N, Yamaguchi H, Tanaka F, Ohta M, Shibuta K, Inoue $\mathrm{H}$, Mori M: Expression of chemokine receptor CCR7 is associated with lymph node metastasis of gastric carcinoma. Cancer Res 2002, 62:2937-41.

13. Wiley HE, Gonzalez EB, Maki W, Wu MT, Hwang ST: Expression of CC chemokine receptor-7 and regional lymph node metastasis of B16 murine melanoma. J Natl Cancer Inst 2001, 93:1638-43.

14. Henning $G$, Ohl $L$, Junt $T$, Reiterer $P$, Brinkmann $V$, Nakano $H$, Hohenberger W, Lipp M, Förster R: CC chemokine receptor 7-dependent and -independent pathways for lymphocyte homing: modulation by FTY720. J Exp Med 2001, 194:1875-81.

15. Okada T, Ngo VN, Ekland EH, Förster R, Lipp M, Littman DR, Cyster JG: Chemokine requirements for $B$ cell entry to lymph nodes and Peyer's patches. J Exp Med 2002, 196:65-75.

16. Stein JV, Soriano SF, M'rini C, Nombela-Arrieta C, de Buitrago GG, Rodríguez-Frade JM, Mellado M, Girard JP, Martínez-AC C: CR7-mediated physiological lymphocyte homing involves activation of a tyrosine kinase pathway. Blood 2003, 101:38-44.

17. Ma F, Zhang SR, Ning L, Sun WX, Liang $X$, Zhang XY, Fu M, Lin C: Construction of eukaryotic expression vector of murine SLC gene and characterization of its chemotactic function. Xi Bao Yu Fen Zi Mian Yi Xue Za Zhi 2003, 19(6):528-30.

18. Buonamici S, Trimarchi T, Ruocco MG, Reavie L, Cathelin S, Mar BG, Klinakis A, Lukyanov Y, Tseng JC, Sen F, Gehrie E, Li M, Newcomb E, Zavadil J, Meruelo D, Lipp M, Ibrahim S, Efstratiadis A, Zagzag D, Bromberg JS, Dustin ML, Aifantis I: CCR7 signaling as an essential regulator of CNS infiltration in T-cell leukemia. Nature 2009, 459(7249):1000-4.

19. Stetler-Stevenson WG, Kleiner DE: Molecular biology of cancer: invasion and metastases. Philadelphia: Lippincott \& Wilkins; 2001, 123-36.

20. Nomura T, Hasegawa $\mathrm{H}$ : Chemokines and anti-cancer immunotherapy: Anti-tumor effect of EBL1-ligand chemokine (ELC) and secondary lymphoid tissue chemokine (SLC). Anticancer Res 2000, 20(6A):4073-4080.

21. Katso R, Okkenhaug K, Ahmadi K, White S, Timms J, Waterfield MD: Cellular function of phosphoinositide-3-kinases: imp lications for development, homeostasis, and cancer. Annu Rev Cell Dev Biol 2001, 17:615-675.

22. Xu X, Sakon M, Nagano H, Hiraoka N, Yamamoto H, Hayashi N, Dono K, Nakamori S, Umeshita K, Ito Y, Matsuura N, Monden M: Akt2 expression correlates with prognosis of human hepatocellular carcinoma. Oncol Rep 2005, 11:25-32.

23. Yamamoto $S$, Tomita $Y$, Hoshida $Y$, Morooka $T$, Nagano $H$, Dono K, Umeshita K, Sakon M, Ishikawa O, Ohigashi H, Nakamori S, Monden M, Aozasa K: Prognostic significance of activated akt expression in pancreatic ductal adenocarcinoma. Clin Cancer Res 2004, 10:2846-2850.

24. Bellacosa A, Kumar CC, Di Cristofano A, Testa JR: Activation of AKT kinases in cancer: implications for therapeutic targeting. Adv Cancer Res 2005, 94:29-86.

25. Altomare DA, Testa JR: Perturbations of the AKT signaling pathway in human cancer. Oncogene 2005, 24:7455-7464.

26. Nicholson KM, Anderson NG: The protein kinase B/Akt signaling pathway in human malignancy. Cell Signal 2002, 14:381-395.

27. Sánchez-Sánchez N, Riol-Blanco L, de la Rosa G, Puig-Kröger A, GarcíaBordas J, Martín D, Longo N, Cuadrado A, Cabañas C, Corbí AL, Sánchez Mateos $P$, Rodríguez-Fernández JL: Chemokine receptor CCR7 induces intracellular signaling that inhibits apoptosis of mature dendritic cells. Blood 2004, 104(3):619.
28. Nabeshima K, Inoue T, Shimao Y, Sameshima T: Matrix metalloproteinases in tumor invasion: role for cell migration. Pathol Annual 2002, 52(4):255-264

29. Sakata K, Satoh M, Someya M, Asanuma H, Nagakura H, Oouchi A, Nakata K Kogawa K, Koito K, Hareyama M, Himi T: Expression of matrix metalloproteinase 9 is a prognostic factor in patients with nonHodgekin's lymphoma. Cancer 2004, 100:356-365.

30. Arlt M, Kopitz C, Pennington C, Watson KL, Krell HW, Bode W, Gansbacher B, Khokha R, Edwards DR, Krüger A: Increase in gelatinasespecificity of matrix metalloproteinase inhibitors correlates with antimetastatic efficacy in a T-cell lymphoma model. Cancer Res 2002, 62(19):5543-5550.

doi:10.1186/1756-9966-30-51

Cite this article as: Yang et al:: Effect of Chemokine Receptors CCR7 on Disseminated Behavior of Human T cell Lymphoma: clinical and experimental study. Journal of Experimental \& Clinical Cancer Research $201130: 51$

\section{Submit your next manuscript to BioMed Central and take full advantage of:}

- Convenient online submission

- Thorough peer review

- No space constraints or color figure charges

- Immediate publication on acceptance

- Inclusion in PubMed, CAS, Scopus and Google Scholar

- Research which is freely available for redistribution

Submit your manuscript at www.biomedcentral.com/submit
C) Biomed Central 